\title{
PALM OIL MILL EFFLUENT'S MICROBIAL FUEL CELL'S OPTIMISATION PROCEDURE BY USING TWO-LEVEL FACTORIAL DESIGN METHOD AND CHEMICAL OXYGEN DEMAND TREATMENT
}

\section{KHAIRUL BAQIR ALKHAIR*; OSKAR HASDINOR HASSAN**; SHARIFAH AMINAH SYED MOHAMED*; YAP KIAN CHUNG ANDREW ${ }^{\ddagger}$; ZULKIFLI AB RAHMAN ${ }^{\ddagger}$ and MOHD ZU AZHAN YAHYA ${ }^{\ddagger \neq}$}

\begin{abstract}
Microbial fuel cell (MFC) technologies represent the newest approach for generating electricity (bioelectricity generation) from biomass using bacteria. Bio-electricity generations by MFC have gained considerable attention due to its integration with wastewater treatment. The objectives of the work are to determine the optimisation of MFC's bio-electrochemical process using three different factors and its interaction, and to determine the optimal $\mathrm{pH}$ value for acidogenic, acetogenic and methanogenic by natural mixed culture electroactive bacteria (exoelectrogens) growth in presence and absence of oxygen using MFC. The two-level factorial design is used in order to achieve the main two objectives. The current generation, power generation and maximum power have been monitored. Experimental result shows that the best interaction between these three factors is (-+-) interaction which is the interaction between tryptic soya broth (TSB), sodium hydroxide as $p H$ controller and resistant of $200 \Omega$, and the interaction yield the power density of $57.44 \mathrm{~mA} \mathrm{~m}^{-2}$. The effects between those interactions also have been analysed. The interaction of all parameters that have been used in this experiment is given out the highest significant effect which is a value of effect of 24.56 with a significant F-value of 29.51. The chemical oxygen demand (COD) reduction by MFC treatment data based on the COD effective deduction concept shows that DMP produced lower percentage of COD effective deduction efficiency compared to $n D M P$. nDMP was $342 \%$ to $441 \%$ more efficient to deduct COD compared to DMP. nDMP 6.8 recorded the most effective COD deduction by MFC devices at $29.17 \%$.
\end{abstract}

Keywords: microbial fuel cell, palm oil mill effluent, 2-level factorial design, chemical oxygen demand.

Date received: 13 July 2017; Sent for revision: 20 July 2017; Received in final form: 16 April 2018; Accepted: 17 July 2018.

Faculty of Applied Science, Universiti Teknologi MARA, 40450 Shah Alam, Selangor, Malaysia.

** Faculty of Art and Design, Universiti Teknologi MARA, 40450 Shah Alam, Selangor, Malaysia.

E-mail: oskar@salam.uitm.edu.my

* Malaysian Palm Oil Board, 6 Persiaran Institusi, 43000 Kajang, Selangor, Malaysia.

** Faculty of Defence Science and Technology, Universiti Pertahanan Nasional Malaysia, 57000 Sungai Besi, Kuala Lumpur, Malaysia.

\section{INTRODUCTION}

Palm oil mill effluent (POME) is a highly-organic wastewater produced by palm oil processing mills. It is usually treated in an open pond system consisting of cooling ponds, acidification ponds, anaerobic ponds and facultative ponds. Through the system, it is able to meet the biological oxygen demand (BOD) discharge limit of $5000 \mathrm{mg}^{\text {litre }}{ }^{-1}$ set by the Malaysian Department of Environment 
(Malaysian Federal Subsidiary Legislation 1978) (Andrew and Manaf, 2013). POME anaerobic fermentation is a complex biochemical process where organic and inorganic matters are degraded to methane and carbon dioxide in discrete steps involving the concerted action of myriad numbers of bacteria in several different metabolite groups of microorganism. The main pathways of anaerobic digestion involve four stages, namely hydrolysis, acidogenesis, acetogenesis and methanogenesis (Andrew and Manaf, 2013), and all these steps are essential to gain the optimal microbial fuel cell's (MFC) performance result.

Recently, the microbial treatment of POME has gained some interest among many scientists and environmentalists, and the application of bacteria in MFC is one of the alternatives for POME treatment (Kang et al., 2017; Tan et al., 2017; Tee et al., 2017). The application of MFC technologies which generate electricity as a by-product is an alternative approach to wastewater treatment (Logan, 2008). In 2004, the relationship between generation electricity using MFC and wastewater treatment was forged when it was demonstrated that domestic wastewaters could be treated to practical levels while simultaneously generating electricity (Liu and Logan, 2004). Bio-electricity generation is a new approach for producing electricity from biomass using bacteria. Therefore, bacteria were further categorised by their ability to exogenously transfer electrons, called exoelectrogens that can produce power in an MFC (Logan, 2008). Other names for exoelectrogens are electrogens, anode-respiring bacteria (Torres et al., 2010) and electrochemically active bacteria/ microorganism (Samir et al., 2010). Exogenously transfer electrons by bacteria are also known as extracellular electron transfer (EET) (Torres et al., 2010).

Design of experiment (DOE) is a well-known method in the engineering field as to determine the cause and effect relationship, which was originally designed for agriculture purposes. DOE is used to evaluate which process inputs would have a significant impact on its output, and what the target level of those inputs should be to achieve a desired output. Planning, designing and analysing are the main processes in DOE. There are three main aspects in DOE, which are factors, levels and response. Factor is the inputs of the process which can be classified either controllable or uncontrollable variables. Level is the settings of each factor in the study. Finally, the respond is the outputs of the experimental works. The purposes of DOE are comparing the alternatives, identifying the significant factors that affecting the response, achieving an optimal process output, reducing variability, improving process, balancing tradeoffs, and finally is to minimise, maximise or target an output (Anderson and Whitcomb, 2007).
Two-level factorial design is conducted for this work. It defines as factorial designs in which each factor is studied at two levels which is at high and low, or present and absent. This method is very important in factor screening experiments and many other scientific investigations. As a first approximation for the model of response controlled by these factors, it is customary to include the main effects and some specified set of two-factor interactions. It was designed to monitor all chosen parameter's main effect and the interaction between them, by doing so we can have a better understanding on the effect of the parameters that we selected. The understanding in the interaction between parameters is a crucial information as to achieve a better performance for this experimental work. This can be achieved by implying the responses of the mains and the interactions of the model into regression model as to predict the responses of designed parameters if different combinations were used (Anderson and Whitcomb, 2007).

During hydrolysis, large polymers of carbohydrate, lipids (fat) and protein macromolecules were broken down to amino acids, long-chain fatty acids and sugars. These hydrolysates were then further fermented during acidogenesis to produce three-, four- and five-carbon volatile fatty acids, where the optimum $\mathrm{pH}$ range for the growth of the acidogenic bacteria was within the $\mathrm{pH}$ ranges between $\mathrm{pH} 5.2$ to $\mathrm{pH}$ 6.5. These hydrolysates were consumed by the acetogenic bacteria generating acetate acids, carbon dioxide and hydrogen during acetogenesis, where the optimum $\mathrm{pH}$ for growth of these bacteria was between $\mathrm{pH} 6.0$ to $\mathrm{pH}$ 7.0. Finally, during methanogenesis, where methanogenic bacteria, which grow within the range of $\mathrm{pH} 7.5$ to $\mathrm{pH} 8.5$, consume the acetate, hydrogen and some of the carbon dioxide to produce methane (Rapport et al. 2008; Solera, et al., 2002).

Apart from the above categorisations, bacteria may be divided into three groups according to their response to free molecular oxygen. These groups are: (1) strictly aerobes, (2) facultative anaerobes and (3) anaerobes which are inactive in the present of free molecular oxygen. Anaerobes may be divided into two subgroups; oxygen-tolerant species and oxygen-intolerant species (Gerardi, 2003). In the second part of this study, mixed POME used was a mixture of raw POME and anaerobic pond POME with the ratio of one is to one (1:1). Anaerobic bacteria present in anaerobic pond POME could be grouped on the basis of their need for oxygen to grow. Obligate anaerobic bacteria (oxygenintolerant species) are bacteria that use an anaerobic metabolism to grow but are harmed and killed in the presence of oxygen. Meanwhile, aerotolerant anaerobic bacteria (oxygen-tolerant species) are also bacteria that use an anaerobic metabolism to grow but could tolerate the presence of oxygen. The 
two categories mentioned above need an anaerobic metabolism to grow, but not for facultative anaerobic bacteria. Facultative anaerobic bacteria prefer to grow using the aerobic metabolism processes but could switch to anaerobic metabolism in the absence of oxygen.

There are two parts in this work, the first part is mixed POME substrates (1:10, raw POME: autoclaved POME) was subjected into three factors that may influence the power generation's output. The first factor was the type of bacteria's broth which are the brain heart infusion (BHI) and tryptic soya broth (TSB). The second factor was the type of $\mathrm{pH}$ controller and for this experiment were $\mathrm{NaOH}$ and $\mathrm{Ca}(\mathrm{OH})_{2}$. The third factor was the external resistance which are $200 \Omega$ and $1000 \Omega$. By using all these factors, its two-levels factorial was designed accordingly, similar pattern was reported by Kala et al. (2016), Samad and Zainol (2017), and Tan et al. (2016). These factors were to investigate in terms of its main and interaction effects and to determine the optimisation of MFC's bio-electrochemical process using the MFC device. This factorial design is to provide significant justification of MFC's power performance. The second part is to determine the optimal $\mathrm{pH}$ value for acidogenic, acetogenic and methanogenic by natural mixed culture electroactive bacteria (exoelectrogens) growth in original raw and anaerobic digested POME mixture (nDMP) and nitrogen deoxygenated raw and anaerobic digested POME mixture (DMP) in MFC is needed.

\section{METHOD}

\section{Part 1: DOE Procedure}

The air cathode double-chambered MFC was made locally using acrylic fibre material with $100 \mathrm{ml}$ of working volume for each component. The anode chamber (anaerobic) and cathode chamber (aerobic) were separated by a salt bridge compartment filled with molten $10 \%$ agarose with $4 \%$ potassium chloride salt (Nair et al., 2013) heated in a water bath which was allowed to be cooled and solidified in room temperature. The salt bridge assists in the proton transfer mechanism during the operational of MFC. The electrode material used for anode and cathode was carbon cloth [activated carbon fibre (ACF) fabric, China] with the sizes of $3.0 \times 3.0 \mathrm{~cm}$ (used in both chambers) with projected area of 9.0 $\mathrm{cm}^{2}$. The anode chamber is sealed to maintain its anaerobic condition. The electrodes close circuit was connected externally through copper wires to provide the permanent connection to external resistance of $1000 \Omega$ or $200 \Omega$ resistor. The schematic diagram of MFC is shown in Figure 1.

The substrate used is mixed POME; a batch of 1.5 litres raw POME was autoclaved for $15 \mathrm{~min}$ at a temperature of $121^{\circ} \mathrm{C}$ at $100 \mathrm{kPa}$ to eliminate living microorganisms entirely. The substrates were prepared in $250 \mathrm{ml}$ borosilicate glass reagent bottles with a mixing ratio of $1: 10$ (20 $\mathrm{ml}$ raw POME to $180 \mathrm{ml}$ of autoclaved POME) with a total of eight

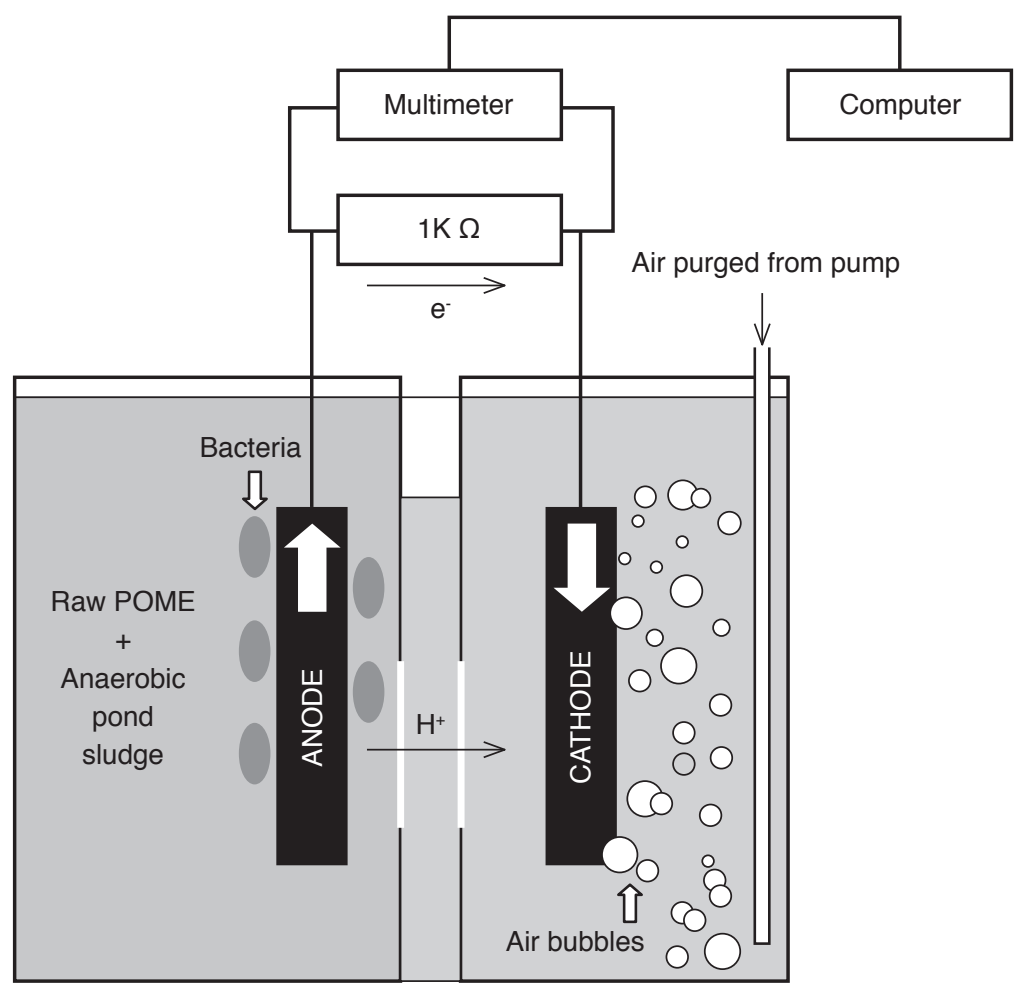

Figure 1. Schematic diagram of aqueous cathode double-chamber microbial fuel cell (MFC). 
bottles. The $\mathrm{pH}$ of the substrates were controlled by using sodium hydroxide $(\mathrm{NaOH})$ or calcium hydroxide $\left[\mathrm{Ca}(\mathrm{OH})_{2}\right]$ maintaining a $\mathrm{pH}$ of $6.8 \pm$ 0.2. Each bottle was subjected to either BHI broth's bacteria or TSB bacteria accordingly. Then, each 250 $\mathrm{ml}$ bottle transferred $100 \mathrm{ml}$ of substrate into $100 \mathrm{ml}$ borosilicate glass reagent bottles as controlled and calibrate sample. After $24 \mathrm{hr}$ of the fermentation process, the leftover substrate of $100 \mathrm{ml}$ in each 250 $\mathrm{ml}$ bottle was used in MFC's operation.

The electrode output voltage was recorded every $15 \mathrm{~min}$ with digital multimeter with data logger (DM620, 50000 Count Logger DMM and UT803, UNI-T). From these data, power generation was calculated using power density normalised by surface area $\left(\mathrm{P}_{\mathrm{A}^{\prime}}, \mathrm{Wm}^{-2}\right)$ (Logan et al., 2006) using Equation (1):

$$
P_{A n}=\frac{V^{2}}{A_{A n} R}
$$

Equation (1)

where $A=$ total area of anode electrode $\left(\mathrm{m}^{2}\right)$, $A n=$ Anode, $P=$ power $(\mathrm{W}), V=$ the potential $(\mathrm{V})$ and $R=$ external resistance $(\Omega)$.

A $2^{3}$ factorial experimental design that study the three main effects, which is type of bacteria's broth, $\mathrm{pH}$ controller and resistor, is as shown in Table 1. A total of eight MFC devices were ran and each factor was carefully monitored at two different levels. High and low levels were the two types of factors that were tested as shown in Table 1. The plus symbol $(+1)$ represents high level and the minus symbol (-1) represents the low level. In this work, as for the type of bacteria's broth of high and low levels were the BHI broth and TSB broth, respectively. The $\mathrm{NaOH}$ and $\mathrm{Ca}(\mathrm{OH})_{2}$ that were used to represent lower and higher levels of the type of $\mathrm{pH}$ controller, respectively. Finally, $200 \Omega$ represents the lower level and $1000 \Omega$ represents the higher level of type of resistor used (Table 1). Each MFC device was ran for five days $(120 \mathrm{hr})$ and all the data was recorded and analysed. The linear model that was used to predict a given responses as Equation (2) .

$$
Y=\beta_{0}+\sum_{i=1}^{n} \beta_{i} X_{i} \quad \text { Equation (2) }
$$

where $Y=$ predicted response, $\beta_{0}=$ model coefficient, $n=$ number of the variable, $\beta_{\mathrm{i}}=$ linear parameters' coefficient, and $X_{i}=$ interaction parameters' coefficient (Samad and Zainol, 2017).

\section{Part 2: POME Treatment}

The double-chambered MFC was designed and fabricated locally using the acrylic fibre material with each compartment working volume of $150 \mathrm{ml}$. The anode (anaerobic) and cathode (aerobic) chamber were separated by a salt bridge compartment filled with molten $10 \%$ agarose with 4\% potassium chloride salt (Nair et al., 2013) heated in a water bath which was then allowed to cool down and solidified where this salt bridge assist in the proton transfer mechanism during MFC's operation. The electrode material used for anode and cathode was carbon brush and the sizes were 2.2 $x 1.6 \times 0.6 \mathrm{~cm}$ (used in both chambers) and $1.3 \times 0.7 \times$ $0.6 \mathrm{~cm}$ (used in anode chamber only) with projected area of anode was $62.22 \mathrm{~cm}^{2}$ and cathode was 11.6 $\mathrm{cm}^{2}$. The electrodes close circuit was connected by using copper wires projecting outside to provide the permanent connection to external resistance of 1000 $\Omega$ resistor. The schematic diagram of microbial fuel cell is shown in Figure 1.

Two mixed POME substrates were prepared in 2-litre beaker with mixing ratio of 1:1 of raw POME and anaerobic pond POME in each beaker. The technique by gas flushing or sparging pure $\mathrm{N}_{2}$ gas (Logan, 2008) through the mixed POME (deoxygenation pre-treatment) was a process to decreased DO (Biffinger et al., 2008; Japar et al., 2013; Logan et al., 2006) in the mixed POME was applied to the first mixed POME sample mixture, DMP, while the second, nDMP, was not. This technique (Biffinger et al., 2008) were done by a large numbers of researchers (Oh et al., 2009; Japar et al., 2013; Biffinger, 2008; Logan, 2008).

Mixed POME (DMP or nDMP), with the three groups of $\mathrm{pH}$ ranges prepared earlier, was used as the substrates for each separate MFC and $125 \mathrm{ml}$ charged in the MFC's anode chamber. The anode chamber was kept in an anaerobic condition by $\mathrm{N}_{2}$ purging and tightly sealed. The cathode chamber was operated in distilled water (aqueous cathode) (Rega, 2006) and constant bubbling with air into the water to provide oxygen to the cathode. The electrode output voltage was recorded against time, measured every $15 \mathrm{~min}$. The anode and cathode

TABLE 1. FACTORS AND LEVELS IN $2^{3}$ FACTORIAL EXPERIMENTAL DESIGN

\begin{tabular}{lcccccc}
\hline No. & Factors & Coded & Type of factor & \multicolumn{2}{c}{ Actual values of coded levels } & Units \\
\cline { 5 - 6 } & & & & $\mathbf{- 1}$ & $+\mathbf{1}$ & \\
\hline 1 & Bacteria's broth & $\mathrm{A}$ & Categorical & TSB & $\mathrm{BHI}$ & - \\
2 & pH controller & $\mathrm{B}$ & Categorical & $\mathrm{NaOH}$ & $\mathrm{Ca}(\mathrm{OH})_{2}$ & - \\
3 & Resistor & $\mathrm{C}$ & Numerical & 200 & 1000 & $\Omega$ \\
\hline
\end{tabular}

Note: TSB - tryptic soya broth.

BHI - brain heart infusion. 
were connected directly to a digital multimeter with data logger (DM620, 50000 Count Logger DMM and UT803, UNI-T). Each day, the $\mathrm{pH}$ value was taken by using digital $\mathrm{pH}$ meter (Professional Bench Top pH Meter BP3001, Trans Instruments, Singapore) and the $\mathrm{pH}$ values were controlled using $\mathrm{NaOH}$ to keep its $\mathrm{pH}$ ranges accordingly. These simple air bubble aqueous cathode MFC with salt bridge dual chamber were operated at ambient temperature from $25^{\circ} \mathrm{C}$ to $28^{\circ} \mathrm{C}$. The voltage reading and its related analysis data will not be shown as this article concentrate on COD analysis.

The COD of the anode substrates was determined by using COD cell test kit Kids (20$1500 \mathrm{mg}$ litre $^{-1}$ range: Hach, USA), digested by using COD reactor (Hach DRB 200, USA) and measured using COD spectrophotometer (Hach DR2800, USA) where COD reading was taken. The initial COD reading was analysed by taking small sample of mixed POME before inserting it in MFC devices. The second COD reading was taken from the MFC anode chamber and the untreated sample on the fifth day. The COD removal efficiency ( $\eta$ ) can be calculated as the ratio between the removed and influent COD (Logan et al., 2006) using Equation (3):

$$
\eta=\frac{C O D_{0}-D O D_{t}}{C O D_{0}} \quad \text { Equation (3) }
$$

where $\mathrm{COD}_{\mathrm{o}}=$ initial $\mathrm{COD}$ of the effluent in the anode chamber, mg litre ${ }^{-1}$ and $\mathrm{COD}_{\mathrm{t}}=\mathrm{COD}$ of the effluent in the anode chamber at measured time (Baranitharan et al., 2013).

\section{RESULTS AND DISCUSSION}

\section{Part 1: DOE Procedure}

Voltage readings were recorded, where power densities were calculated, by the MFC devices for all designed factors in $2^{3}$ factorial design as shown in Table 2. In Figure 2, the graph is divided into

TABLE 2. THE DESIGN OF THE $2^{3}$ FRACTIONAL FACTORIAL EXPERIMENTS

\begin{tabular}{ccccc}
\hline Standard order & \multicolumn{2}{c}{ Coded values of variables } & Power density $\left(\mathbf{m W m}^{-2}\right)$ \\
\cline { 2 - 5 } & A & B & C \\
\hline $1(--)$ & -1 & -1 & -1 & 5.12 \\
$2(+-)$ & +1 & -1 & -1 & 7.68 \\
$3(-+-)$ & -1 & +1 & -1 & 57.44 \\
$4(++-)$ & +1 & +1 & +1 & 4.12 \\
$5(--+)$ & -1 & -1 & +1 & 41.48 \\
$6(+-+)$ & +1 & -1 & +1 & 8 \\
$7(-++)$ & -1 & +1 & +1 & 6.28 \\
$8(+++)$ & +1 & +1 & & 15.16 \\
\hline
\end{tabular}

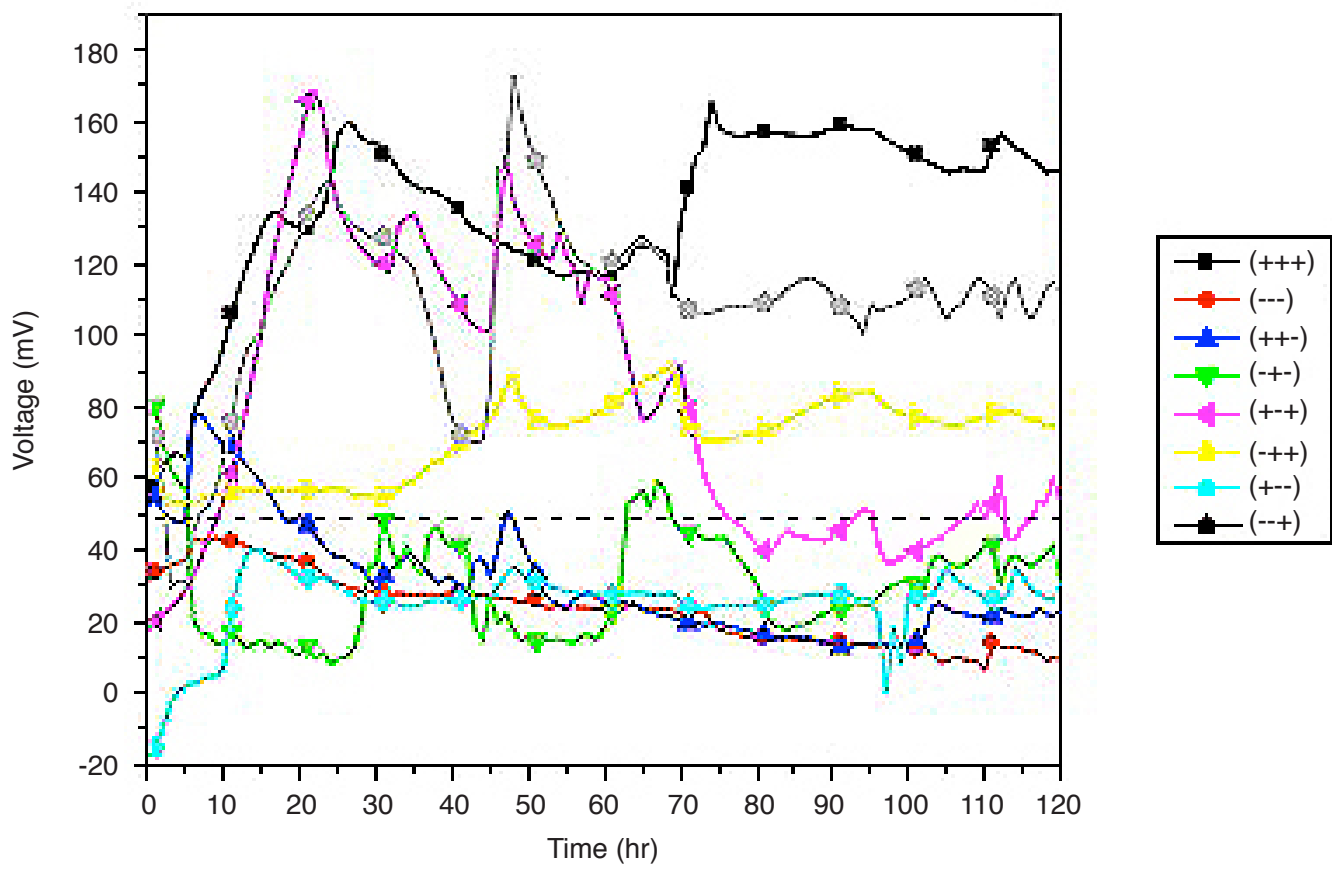

Figure 2. Microbial fuel cell's (MFC) electricity production of all factors in five days. 
two sections which are $1000 \Omega$ (upper dotted-line) and $200 \Omega$ (lower dotted-line). Since there are two external resistances involved in the experiment, the electricity generation in Figure 2 is not suitable to be used to compare the relationship between the designed factors and the generated current. The different resistors used for the experimental work make the electricity generated tend to be differ as well. As the external load is higher, the electricity that was generated also higher which apply by the formula of $\mathrm{V}=\mathrm{IR}$. The electricity generation can only be refer if the external resistor is constant, however it can be used to understand the mechanism of electricity generation and the behaviour of the electrons transferred in the system over time. A similar approach was reported by Jadhav and Ghangrekar (2009).

The power densities of all designed factors were calculated, and the comparison of all designed factors' power generation are as shown in Figure 3. In the graph, only three peaks that have significant readings as compared to others which are factors $(-+-),(--+)$ and $(+++)$. Factor (-+-) recorded the highest maximum power generated as compared to $(--+)$, that is the second highest, and lastly $(+++)$. (-+-) yielded a maximum power of $57.44 \mathrm{mWm}^{-2}$. Factors (--+) and (+++) generated maximum power of $41.48 \mathrm{mWm}^{-2}$ and $15.16 \mathrm{mWm}^{-2}$, respectively. As shown in Figure 3, the maximum powers' peak for both factors (-+-) and (--+) is peaked at resistance of $200 \Omega$, and $1000 \Omega$ is where the maximum power of $(+++)$ is peaked. The reason behind these results are due to correspondence of the growth of bacteria with the external resistance that were used in the experiment (Liu et al., 2008), but that is not in all cases because in this work, factor (--) shows a different result. Although, $1000 \Omega$ was used in factor (--+) but the maximum power's peak which supposed to be $1000 \Omega$, but it lies on $200 \Omega$ instead. It is proven that bacteria's growth and external resistance play an important role in power density generation, but external resistance is not the only factor that determine its maximum power. Other factor that determine maximum power is the differences between external and internal resistance. The smaller the differences, the higher the power density will be produced (Logan, 2008). The relationship between bacteria's growth and external resistance, that effects the maximum power generation, will be more precise, if and only if, we able to eliminate or reduce the internal resistance in a MFC system.

The $2^{3}$ Factorial work was carried out, in two levels of high and low. The analysis of variance (ANOVA) for MFCs' power densities were done as to determine the significance of the designed model as shown in Table 3. The F-values is the indication whether the regression equation significant or not (Samad and Zainol, 2017). F-values can be obtained by dividing the sum of squares (SS) with degree of freedom (df) for each factor. From the Table 3, 21.63 is the F-value for this model with the p-value of 0.006 with a percentage of $99 \%$ confident that the model is significant. Any model that has percentage F-distribution of above $95 \%$, that model is consider a significant model with the percentage of $5 \%$ to null hypothesis (Anderson and Whitcomb, 2007). The statistically significant factors for this model is

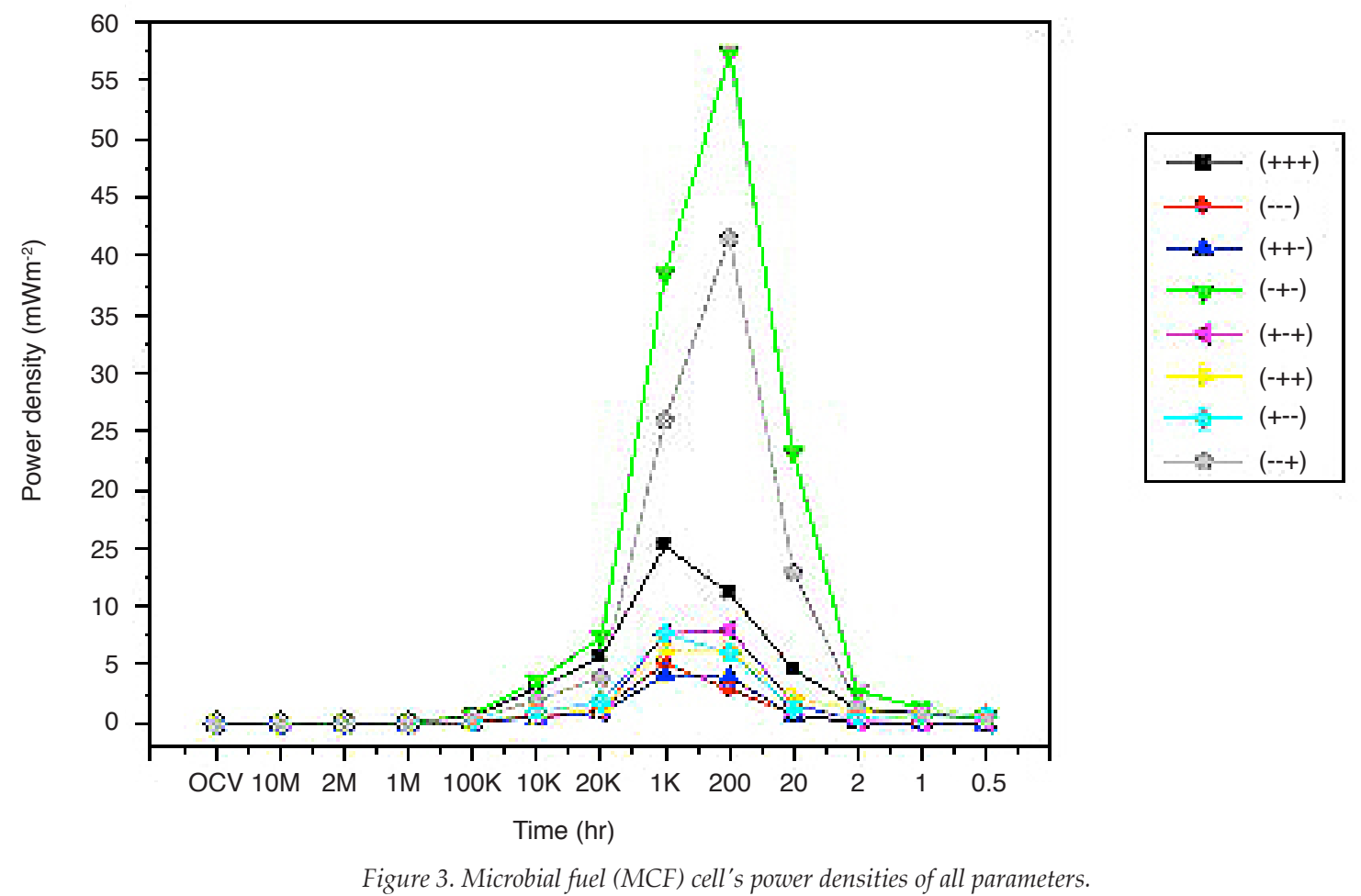


TABLE 3. TEST OF SIGNIFICANCE FOR REGRESSION COEFFICIENT

\begin{tabular}{cccccc}
\hline Source & Coefficient & Sum of squares & Mean square & F-value & Prob $>$ F \\
\hline Model & 18.16 & 2653.6 & 884.52 & 709.9 & 21.63 \\
A & -9.42 & 709.9 & 737.3 & 17.36 & 0.006 \\
BC & -9.60 & 737.3 & 1206.4 & 29.51 & 0.014 \\
ABC & 12.28 & 1206.4 & 40.88 & - & 0.006 \\
Residual & - & 163.5 & - & - & - \\
Cor Total & - & 2817.1 & & \\
\hline
\end{tabular}

$A, B C$ and $A B C$ in MFC performance, and the nonsignificant factors in the model is $B, C, A B$, and $A C$. The non-significant factors in the model will be the residuals that be used as an optimality criterion (Anderson and Whitcomb, 2007).

From the ANOVA, the value of coefficient of determination $\left(R^{2}\right)$ is calculated. $R^{2}$ is used to study the relationship between the factors used and responses from each parameter, and also to understand the level and effect of each independent parameter (Kala et al., 2016). It is suggested by Karazhiyan et al. that a good fitting model must have a large $\mathrm{R}^{2}$ and not least then $80 \%$ (Karazhiyan et al., 2011). The $R^{2}$ and adjusted- $R^{2}$ value for this model is satisfactory with the coefficient value of 0.9419 and 0.8984 , respectively. The effect of the factors on responses was predicted by using the standard mathematical regression equation [Equation (4)] as follows:

$$
\mathrm{Y}=18.16-9.42 \mathrm{~A}-9.60 \mathrm{~B}+12.28 \mathrm{ABC} \quad \text { Equation }(4)
$$

where $Y$ is response of MFC's power density. $A$ represents bacteria's broth. $B$ represents $\mathrm{pH}$ controller and $C$ represents resistor as shown in Table 1. The factors $A, B$ and $C$ are the main effects while $A B, A C, B C$ and $A B C$ are the interaction effects of the model (Anderson and Whitcomb, 2007).

The Pareto chart is very helpful in showing the relative size of effects and easily determining the most significant parameters in the model. In Pareto chart, $\mathrm{t}$-values are used to increase the eligibility of the chart. The $\mathrm{t}$-values can be obtained by square root the F-value. There are actually two limit lines shown in Pareto chart which are the Bonferroni limit line, which is a stricter level of 0.025 by dividing p-value of 0.05 by 2 , and $t$-value limit line with the critical t-value of 2.776 and 5.068 , respectively (Anderson and Whitcomb, 2007). Figure 4, shows the Pareto chart of the model and it is clear that the factor $A B C, B C$ and $A$ exceed the critical t-value limit line which indicates significant effects for MFC's power density specificallt for this model.

Among the three factors that exceed the t-value, only one factor exceeding the Bonferroni limit which is $A B C$ with the value of 5.432 , while $B C$ is the second highest with the value of 4.246. $A$ is the highest and only main factor that exceed the t-value limit line with the value 4.167. In this model, interaction between all factors, which are bacteria's broth, $\mathrm{pH}$ controller and external resistance, is proven plays a crucial role in MFC's performance.

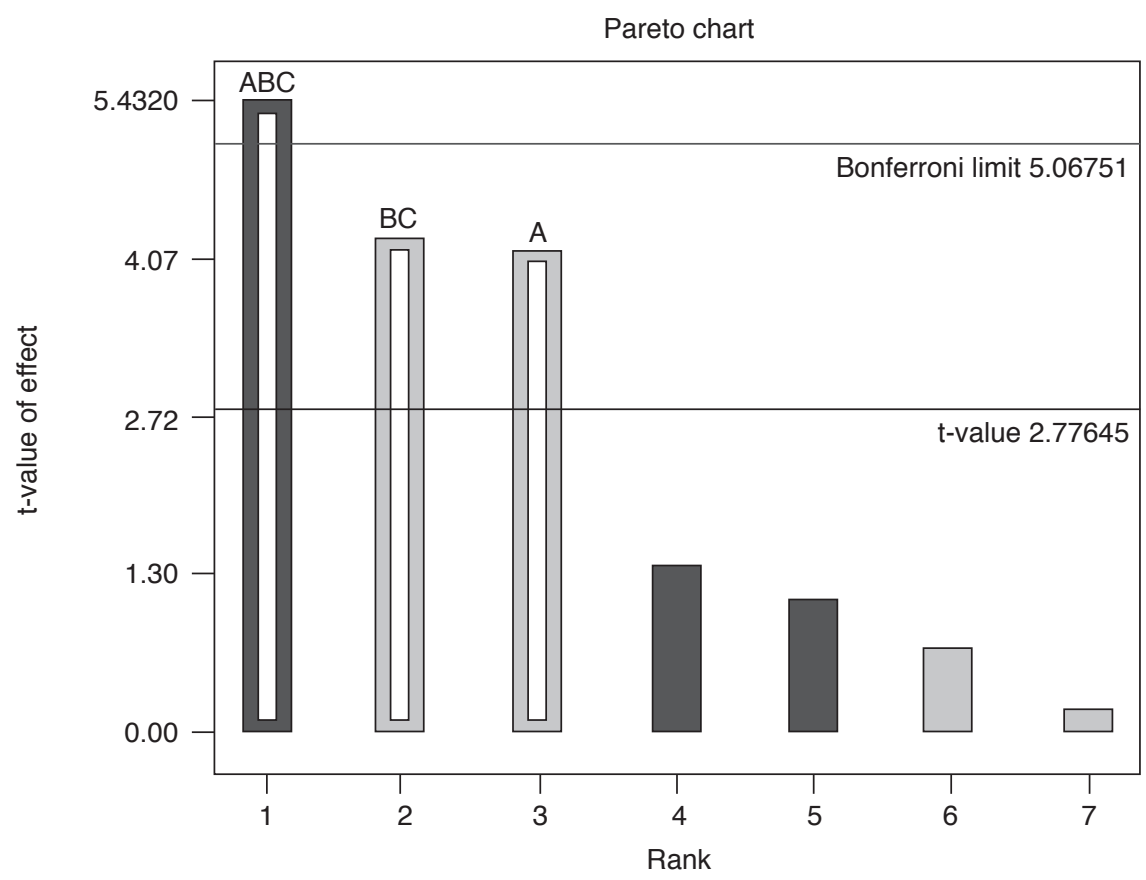

Figure 4. Pareto chart showing a relative effect of factors on microbial fuel cell's (MFC) performance. 
MFC's study on the type of bacteria broth used in MFC system is currently not available, but the bacteria broth that were used in this work, promote different growth of bacteria community (Sottile and Zabransky, 1977) and also reported by Logan et al. that the most researcher choosen their media carefully to culture their bacteria at optimal level (Logan, 2008). The growth of a better exoelectrogens commnity in TSB media made bacteria's broth a significant factor in this model. $B C$ outcome in this model is as predicted because both factors are determining the growth of bacteria's community in the MFC system (Jadhav and Ghangrekar, 2009). The $\mathrm{Ca}(\mathrm{OH})_{2}$ is better than $\mathrm{Na}(\mathrm{OH})$ at maintaning the $\mathrm{pH}$ value and keeping the bacteria in its optimal $\mathrm{pH}$ condition (Fernandes et al., 2009). Resistance of $200 \Omega$ given a better output than its higher level of factorial design which also aligned with Jadhav et al. study as they stated that a lower resistance produced a higher current generation (Jadhav and Ghangrekar, 2009). Although, $A$ and $B C$ exceed the $\mathrm{t}$-value critical limit line, but $A B C$, that exceed both $\mathrm{t}$-value and Bonferroni limit line, plays much bigger role in this model. This is proven that all factors are important in enhancing the performance of MFC's system. From this model, we can conclude that the optimal parameters for MFC's performance is TSB bacteria broth, $\mathrm{Ca}(\mathrm{OH})_{2}$ as $\mathrm{pH}$ controller and $200 \Omega$ of external resistance.

\section{Part 2: COD Reduction}

Effect of $p H$ to COD reduction using DMP and nDMP treated by MFC devices. In Figure 5, DMP 8.0 is the highest net COD reduction treated by MFC devices in percentages and $\mathrm{mg}$ litre $^{-1}$ for DMP, that recorded $25.45 \%$ reduction that equal to $28500 \mathrm{mg}$ litre $^{-1}$ and it was $6.70 \%$ higher than the calibrate DMP 8.0. It was followed by treated DMP 5.5 with $16.52 \%$ reduction that equal to $18500 \mathrm{mg}^{\text {litre }}{ }^{-1}$ which was $6.69 \%$ higher than the calibrate DMP 5.5 and treated DMP 6.8 with $12.05 \%$ reduction that equal to 13500 mg litre ${ }^{-1}$ and this was $4.47 \%$ higher than calibrate DMP 6.8 as shown in Table 4. From Table 5, the highest net COD reduction treated by MFC devices in percentages and $\mathrm{mg}$ litre $^{-1}$ for nDMP was with nDMP 5.5 that recorded $42.36 \%$ reduction that equal to $122000 \mathrm{mg}$ litre $^{-1}$ and it was $20.48 \%$ higher than the calibrate DMP 5.5. It than followed by nDMP 6.8 with $30.56 \%$ reduction that equal to $88000 \mathrm{mg}$ litre $^{-1}$ that was $29.17 \%$ higher than the calibrate DMP 6.8 and nDMP 8.0 with $13.19 \%$ reduction that equal to $38000 \mathrm{mg} \mathrm{litre}^{-1}$ and it was $11.45 \%$ higher than the calibrate DMP 8.0. Overall, the COD reduction recorded for MFC treated DMP and nDMP substrates indicate higher COD reduction as compared to the calibrate DMP and nDMP substrates. This was in accordance with previous work that MFC has the ability to treat POME by deducting the COD level as they were using natural microflora and isolated pure culture bacteria from anaerobic POME sludge in the MFC system (Md Nor et al., 2015).

The main pathways of anaerobic digestion involved four stages which usually start with hydrolysis than followed by acidogenesis, acetogenesis and methanogenesis. If considered the fermentation pathways were done in the twostage anaerobic digestion system, where the first

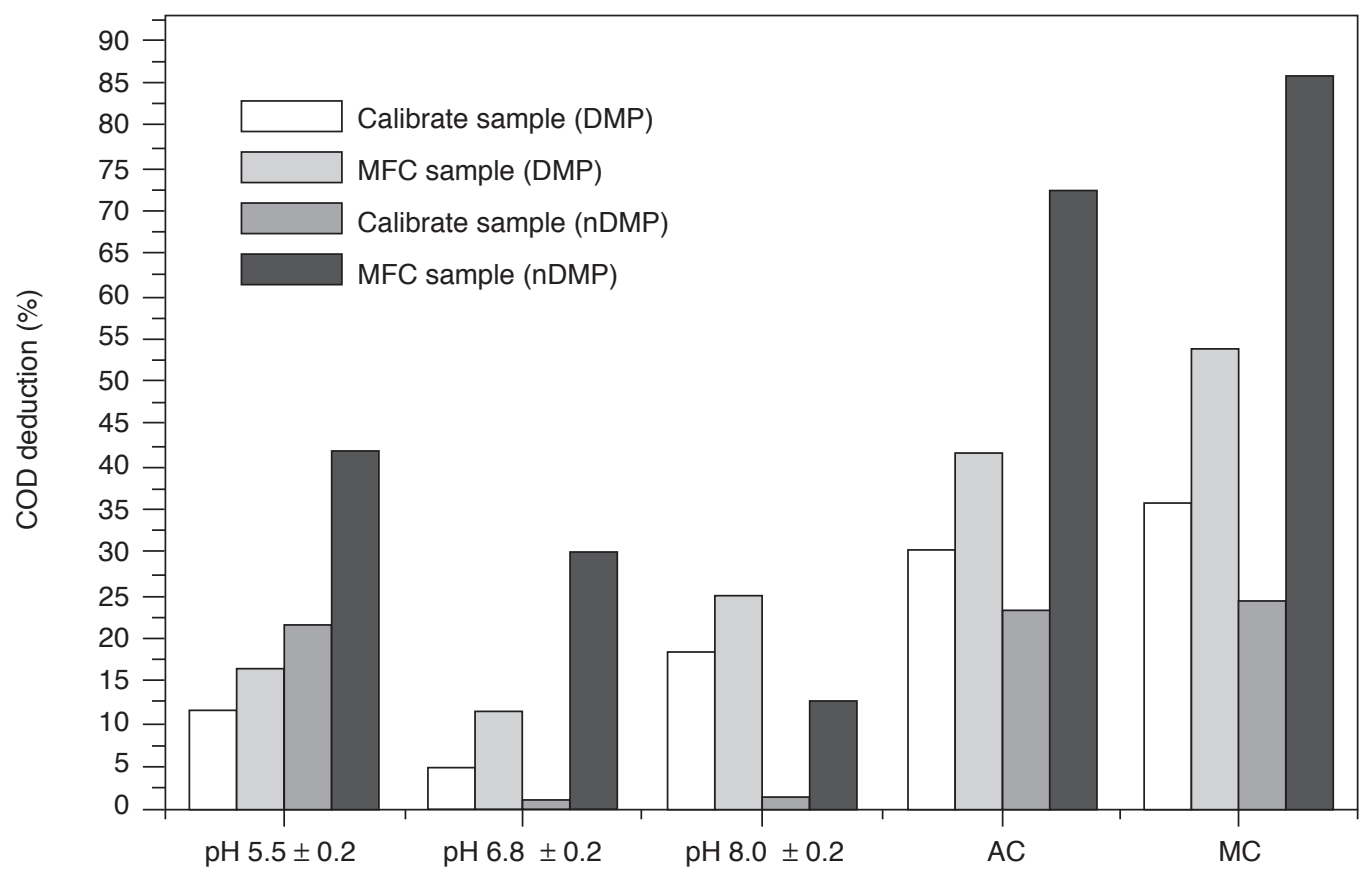

Figure 5. Chemical oxygen demand (COD) reduction with anaerobic digested POME mixture (DMP) and nitrogen deoxygenated POME mixture $(n D M P)$ treated by microbial fuel cell (MFC) at difference $\mathrm{pH}$ ranges. 
TABLE 4. CHEMICAL OXYGEN DEMAND (COD) EFFECTIVE REDUCTION EFFICIENCY OF MICROBIAL FUELL CELL (MFC) WITH DMP AT DIFFERENT $\mathrm{pH}$ VALUES

\begin{tabular}{|c|c|c|c|c|c|c|}
\hline & \multicolumn{2}{|c|}{$\mathrm{pH}$ of $5.5 \pm 0.2$} & \multicolumn{2}{|c|}{$\mathrm{pH}$ of $6.8 \pm 0.2$} & \multicolumn{2}{|c|}{$\mathrm{pH}$ of $8.0 \pm 0.2$} \\
\hline Before MFC treatment (mg litre $\left.{ }^{-1}\right)$ & 112000 & 112000 & 112000 & 112000 & 112000 & 112000 \\
\hline After MFC treatment (mg litre ${ }^{-1}$ ) & 93500 & 98500 & 98500 & 106000 & 83500 & 91000 \\
\hline Net COD reduction (mg litre ${ }^{-1}$ ) & 18500 & 13500 & 13500 & 6000 & 28500 & 21000 \\
\hline$\%$ of COD reduction & 16.52 & 12.05 & 12.05 & 5.36 & 25.45 & 18.75 \\
\hline
\end{tabular}

TABLE 5. CHEMICAL OXYGEN DEMAND (COD) EFFECTIVE REDUCTION EFFICIENCY OF MICROBIAL FUEL CELL (MFC) WITH nDMP AT DIFFERENT pH VALUES

\begin{tabular}{|c|c|c|c|c|c|c|}
\hline & \multicolumn{2}{|c|}{$\mathrm{pH}$ of $5.5 \pm 0.2$} & \multicolumn{2}{|c|}{$\mathrm{pH}$ of $6.8 \pm 0.2$} & \multicolumn{2}{|c|}{$\mathrm{pH}$ of $8.0 \pm 0.2$} \\
\hline Before MFC treatment (mg litre $\left.{ }^{-1}\right)$ & 288000 & 288000 & 288000 & 288000 & 288000 & 288000 \\
\hline After MFC treatment (mg litre ${ }^{-1}$ ) & 166000 & 225000 & 200000 & 284000 & 250000 & 283000 \\
\hline Net COD reduction (mg litre ${ }^{-1}$ ) & 122000 & 63000 & 88000 & 4000 & 38000 & 5000 \\
\hline$\%$ of COD reduction & 42.36 & 21.88 & 30.56 & 1.39 & 13.19 & 1.74 \\
\hline
\end{tabular}

Note: nDMP - nitrogen deoxygenated POME mixture.

stage by hydrolysis and acidogenesis stages in acidogenic reactor than followed by acetogenesis and methanogenesis stages in methanogenic reactor, therefore the total COD reduction was calculated by adding COD reduction by acidogenesis, acetogenesis and methanogenesis (MC). If considered that the stage of acetogenesis and methanogenesis cohabit (AC) and digested the same substrate, therefore the higher COD reductions between the two pathways were used in the calculation, which was reported by Cheng et al. (2010). In Figure 5, the total calculated percentages of COD reduction for DMP treated by MFC devices for $\mathrm{pH} 5.5 \pm 0.2, \mathrm{pH} 6.8 \pm 0.2$ and $\mathrm{pH}$ $8.0 \pm 0.2$ was between $41.97 \%$ to $54.02 \%$ and these readings were higher than DMP untreated by MFC devices which was between $30.80 \%$ to $36.16 \%$.

On the other hand, there was an increase of $11.17 \%$ to $17.86 \%$ COD reduction for DMP between untreated and treated by MFC devices. The total calculated percentages of COD reduction for $\mathrm{nDMP}$ treated by MFC devices for $\mathrm{pH} 5.5 \pm 0.2$, $\mathrm{pH} 6.8 \pm 0.2$ and $\mathrm{pH} 8.0 \pm 0.2$ was between $72.92 \%$ to $86.11 \%$ and these readings were higher than $\mathrm{nDMP}$ untreated by MFC devices which was between $23.62 \%$ to $25.01 \%$. There was an increase of $49.30 \%$ to $61.10 \%$ COD reduction for $\mathrm{nDMP}$ between untreated and treated by MFC devices as shown in Figure 5. The trends of COD reductions were also observed in the previous report where they used a two-stage MFC system integrated with immobilised biological aerated filters to treat POME. They found that by combining the hydrolysis and acidogenesis stages in acidogenic reactor than followed by acetogenesis and methanogenesis stages in methanogenic reactor enhanced the rate of COD reduction in MFC system (Cheng et al., 2010).

The COD effective reduction efficiency by MFC device. All the above recorded data does not reflect the true COD effective reduction by MFC devices. There were COD reduction processes done by the existing microorganism in the substrates that was not subjected to MFC devices which also contribute to the COD reduction. The percentages of MFC treated samples of nDMP and DMP were relatively higher than the calibrated sample. Therefore, the difference in these two percentages of COD reduction between the MFC devices and the calibrated sample were considered as the percentages of COD effective reduction by $M F C$, showing the true percentages of COD reduction by MFC devices (Table 6). This finding cannot be compared to the available reports due to the different approach of columbic efficiency method (Ghasemi et al., 2011; 2012; Hassan et al., 2014; Xing et al., 2015). Columbic efficiency is a common approach taken by other MFC's researchers to study the effectiveness of redox reaction during electrochemical reaction. Most researchers included the columbic efficiency to determine the performance of the MFC's device but this article only determines the MFC optimisation. The reason why the columbic efficiency was not included is due to the different approach used and it is also not included in the objectives of the experiment.

The highest percentages of COD effective reduction by MFC treated sample of nDMP were $29.17 \%$ for $\mathrm{nDMP}$ 6.8, while $\mathrm{nDMP} 5.5$ recorded $20.48 \%$ and $11.45 \%$ for by nDMP 8.0 were relatively 
TABLE 6. COMPARISON CHEMICAL OXYGEN DEMAND (COD) EFFECTIVE REDUCTION EFFICIENCY OF MICROBIAL FUEL CELL (MFC) FOR BOTH DMP AND nDMP AT DIFFERENT $\mathrm{pH}$ VALUES

\begin{tabular}{|c|c|c|c|c|c|c|}
\hline & \multicolumn{2}{|c|}{$\mathrm{pH}$ of $5.5 \pm 0.2$} & \multicolumn{2}{|c|}{$\mathrm{pH}$ of $6.8 \pm 0.2$} & \multicolumn{2}{|c|}{$\mathrm{pH}$ of $8.0 \pm 0.2$} \\
\hline & DMP & nDMP & DMP & nDMP & DMP & nDMP \\
\hline Net COD reduction (mg litre $\left.{ }^{-1}\right)$ & 5000 & 59000 & 7500 & 84000 & 7500 & 33000 \\
\hline Ratio DMP:nDMP for net COD reduction (mg litre $\left.{ }^{-1}\right)$ & 1.00 & 11.80 & 1.00 & 11.20 & 1.00 & 4.40 \\
\hline$\%$ of COD effective reduction by MFC & 4.47 & 20.48 & 6.69 & 29.17 & 6.70 & 11.45 \\
\hline$\%$ ration DMP:nDMP for COD effective reduction by MFC & 1.00 & 4.58 & 1.00 & 4.36 & 1.00 & 1.71 \\
\hline Different in $\%$ of COD effective reduction by MFC & 16.01 & - & 22.48 & - & 4.75 & - \\
\hline
\end{tabular}

Note: DMP - anaerobic digested POME mixture. nDMP - nitrogen deoxygenated POME mixture.

higher than MFC treated sample of DMP which were $6.7 \%$ and $6.69 \%$ for DMP 8.0 and DMP 6.8 respectively but only $4.46 \%$ for DMP 5.5 as shown in Figure 6.

The highest percentage of COD effective reduction by MFC sample from nDMP group is nDMP 6.8 which is $29.17 \%$, and the percentages of $\mathrm{nDMP} 5.5^{\prime} \mathrm{s}$ and $\mathrm{nDMP}$ 8.0's effective COD reduction were $20.48 \%$ and $11.45 \%$, respectively. As for DMP group, the percentages of effective COD reduction done by DMP 5.5, DMP 6.8 and DMP 8.0 were $4.47 \%, 6.69 \%$ and $6.70 \%$, respectively. For DMP, the percentage of COD Effective Reduction by MFC was between $4.47 \%$ to $6.70 \%$, while for nDMP was between $11.45 \%$ to $29.17 \%$. In this work, nDMP substrates show a better COD reduction than DMP. These were in line with the conclusions from previous study that the current generations by MFC accelerated the COD reduction (Zhang et al., 2015).

In Figure 6, if the MFC devices operation were applied as a two-stage anaerobic digestion system as mentioned earlier, the total calculated percentages of COD reduction for $\mathrm{nDMP}$ treated by MFC devices for $\mathrm{pH} 5.5 \pm 0.2, \mathrm{pH} 6.8 \pm 0.2$ and $\mathrm{pH} 8.0 \pm 0.2$ were between $49.30 \%$ to $61.10 \%$ and these reading were higher compared to DMP by MFC devices which was between $11.17 \%$ to $17.86 \%$. Similar application was observed in (Cheng et al., 2010).

\section{CONCLUSION}

In conclusion, the experimental result (Part 1) shows that the best interaction between these three factors is (-+-) interaction which is the interaction between TSB broth, $\mathrm{Ca}(\mathrm{OH})_{2}$ as $\mathrm{pH}$ controller and resistant of $200 \Omega$, with the effect value of 24.56, and this interaction yields the power density of 57.44 $\mathrm{mAm}^{-2}$. The DOE model of this work is found to be significant with the F-value of 21.63. The most significant parameter of this work is ABC with the F-value of 24.56 which exceed both Bonferroni and critical t-value limit line in the Pareto chart (Part 2). Two conclusions can be drawn in this work. Firstly,

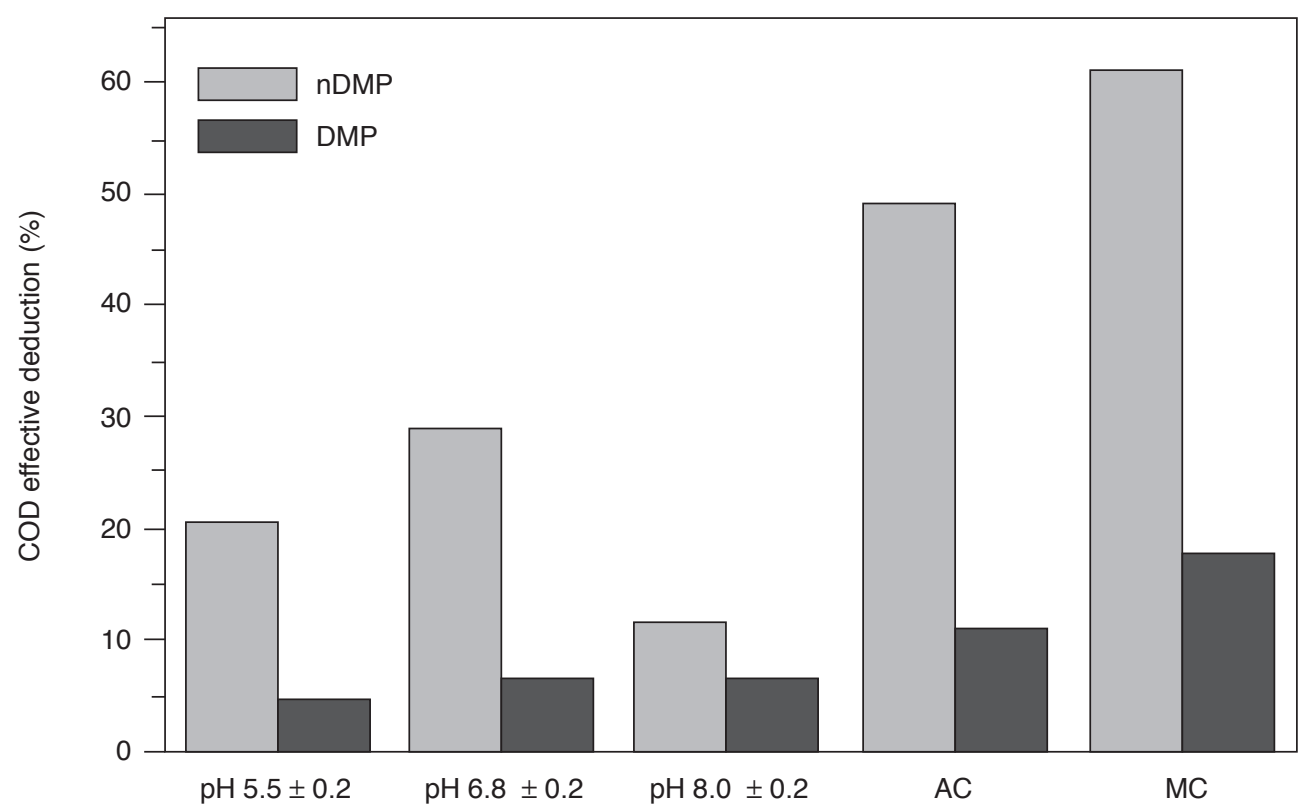

Figure 6. Chemical oxygen demand (COD) reduction comparison of anaerobic digested POME mixture (DMP) and nitrogen deoxygenated ( $n D M P)$ treated by microbial fuel cell (MFC) at different $p H$ ranges. 
DMP produced a relatively lower percentage of COD effective deduction efficiency compared to nDMP. Secondly, the percentage COD effective deduction efficiency treatment by MFC devices using $\mathrm{nDMP}$ was better than DMP. The $\mathrm{nDMP}$ was $342 \%$ to $441 \%$ more efficient to deduct COD compare to DMP. The nDMP 6.8 recorded the most effective COD deduction by MFC devices at $29.17 \%$ although nDMP 5.5 recorded a higher COD deduction than nDMP 6.8 but its COD effective deduction efficiency was only at $20.48 \%$.

\section{ACKNOWLEDGEMENT}

The authors would like to thank the Ministry of Education Malaysia; Universiti Teknologi MARA (UiTM) and MPOB for funding [Research Acculturation Grant Scheme (RAGS) and Graduate Students Assistanship Scheme (GSAS)] this project. We are thankful to UiTM for providing the facilities and to FECLRA Palm Oil Factory Nasaruddin located in Bota, Perak for providing the POME samples.

\section{REFERENCES}

ANDERSON, MARK J and PATRICK J WHITCOMB (2007). DOE Simplified Practical Tools for Effective Experimentation. Third edition. Taylor \& Francis Group.

ANDREW, Y K C and MANAF, F Y A (2013). 'Fermentation pathway for palm oil mill effluent. Palm Oil Engineering Bulletin No. 109.

BIFFINGER, J C; JACQUELINE N BYRD; BREANNA L DUDLEY and BRADLEY R RINGEISEN (2008). Oxygen exposure promotes fuel diversity for shewanella oneidensis microbial fuel cells. Biosensors and Bioelectronics, 23: 820-826.

CHENG JIA; XIUPING ZHU; JINREN NI and ALISTAIR BORTHWICK (2010). Palm oil mill effluent treatment using a two-stage microbial fuel cells system integrated with immobilized biological aerated filters. Bioresource Technology, 101(8): 27292734 .

BARANITHARAN, E; MAKSUDUR R KHAN and PRASAD, D M R (2013). Treatment of palm oil mill effluent in microbial fuel cell using polyacrylonitrile carbon felt as electrode. J. Medical and Bioengineering, 2(4): 252-256.

FERNANDES, T V; KAASSE BOS, G J; ZEEMAN, G; SANDERS, J P M and VAN LIER, J B (2009). Effects of thermo-chemical pre-treatment on anaerobic biodegradability and hydrolysis of lignocellulosic biomass. Bioresource Technology, 100(9): 2575-2579.

GHASEMI, M; RAMLI, W; DAUD, W; ISMAIL, M; RAHIMNEJAD, M; FAUZI, A; XING, J; MISKAN, $\mathrm{M}$ and BEN, K (2012). Effect of pre-treatment and biofouling of proton exchange membrane on microbial fuel cell performance. International J. Hydrogen Energy, 38(13): 5480-5484.

GHASEMI, M; SAMANEH SHAHGALDI; MANAL ISMAIL and BYUNG HONG (2011). Activated carbon nanofibers as an alternative cathode catalyst to platinum in a two-chamber microbial fuel cell. International J. Hydrogen Energy, 36(21): 13746-13752.

GERARDI, M (2003). The Microbiology of Anaerobic Digesters.

HASSAN, S H A; EL-RAB, S M F G; RAHIMNEJAD, M; GHASEMI, M; JOO, J; SIK-OK, Y and KIM, I S (2014). Electricity generation from rice straw using a microbial fuel cell. International J. Hydrogen Energy, 39(17): 9490-9496.

JADHAV, G S and GHANGREKAR, M M (2009). Performance of microbial fuel cell subjected to variation in $\mathrm{pH}$, temperature, external load and substrate concentration. Bioresource Technology, 100(2): 717-723.

JAPAR, A S; TAKRIFF, M S; JAHIM, J $M$ and KADHUM, A A H (2013). Acetone-butanol-ethanol fermentation from palm oil mill effluent using clostridium acetobutylicum. Developments in Sustainable Chemical and Bioprocess Technology. p. 35-41.

KALA MANIKA; MUHAMMAD VASEEM SHAIKH and MANISH NIVSARKAR (2016). Development and optimization of psychological stress model in mice using 2 level full factorial design. J. Pharmacological and Toxicological Methods, 82: 54-61.

KANG YEE LI; SARAVANAN PICHIAH and SHALIZA IBRAHIM (2017). Facile reconstruction of microbial fuel cell (MFC) anode with enhanced exoelectrogens selection for intensified electricity generation. International J. Hydrogen Energy, 42(3): 1661-1671.

KARAZHIYAN, H; RAZAVI , S M A and GLYN O PHILLIPS (2011). Extraction optimization of a hydrocolloid extract from cress seed (Lepidium Sativum) using response surface methodology. Food Hydrocolloids, 25(5): 915-920.

LIU HONG and BRUCE E LOGAN (2004). Electricity generation using an air-cathode single chamber microbial fuel cell in the presence and absence of a 
proton exchange membrane. Environmental Science \& Technology, 38(14): 4040-4046.

LIU, Y; HARNISCH, F; FRICKE, K; SIETMANN, $R$ and SCHRODER, $U$ (2008). Improvement of the anodic bioelectrocatalytic activity of mixed culture biofilms by a simple consecutive electrochemical selection procedure. Biosensors and Bioelectronics, 24(4): 1006-1011.

LOGAN, B E; WILLY VERSTRAETE and KORNEEL RABAEY (2006). Critical review microbial fuel sells . Methodology and Technology, 40(17): 5181-5192.

LOGAN, B E (2008). Microbial Fuel Cells. John Wiley \& Sons, Inc.

LOGAN, B E; HAMELERS, B ROZENDAL, R; SCHRODER, U; KELLER, J; FREGUIA, S; AELTERMAN, P; VERSTRAETE, $\mathrm{W}$ and RABAEY, K (2006). Microbial fuel cells: methodology and technology. Environmental Science and Technology, 40(17): 5181-5192.

MALAYSIAN FEDERAL SUBSIDIARY LEGISLATION (1978). Environmental Quality Act 1974.

NOR, M H M; MUBARAK, M F M; ELMI, H S A; IBRAHIM, N; WAHAB, M F A and IBRAHIM, Z (2015). Bioelectricity generation in microbial fuel cell using natural microflora and isolated pure culture bacteria from anaerobic palm oil mill effluent sludge. Bioresource Technology.

NAIR, R; RENGANATHAN, K; BARATHI, $\mathrm{S}$ and VENKATRAMAN, K (2013). Concentrations Using Hostel Sewage Waste as Substrate, 2(5): 326-330.

OH, S E; KIM, J R; JOO, J H and LOGAN, B E (2009). Effects of applied voltages and dissolved oxygen on sustained power generation by microbial fuel cells. Water Science and Technology, 60: 1311-1317.

RAPPORT, J; ZHANG, R; JENKINS, B $\mathrm{M}$ and WILLIAMS, R B (2008). Current anaerobic digestion technologies used for treatment of municipal organic solid waste. California Integrated Waste Management Board (March). p. 90.

REGA LOGAN, B E and JOHN, M (2006). Microbial challenges and fuel cell applications. Environmental Science \& Technology: 5172-5180.

SAMAD, K A and ZAINOL, N (2017). The use of factorial design for ferulic acid production by coculture. Industrial Crops and Products, 95: 202-206.
SAMIR, K K; RAO, Y S; ZHANG, T C; BUDDHI, P L; TYGI, R D and KAO, C M (2010). Bioenergy and biofuel from biowastes and biomass. Institute of the American Society of Civil Engineers, 6: 116-126.

SOLERA, R; ROMERO, L I and SALES, D (2002). The evolution of biomass in a two-phase anaerobic treatment process during start-up. Chemical and Biochemical Engineering Quarterly, 16(1): 25-29.

SOTTILE, W and ZABRANSKY, R J (1977). Comparative growth rates of selected anaerobic species in four commonly used broth media. Antimicrobial Agents and Chemotherapy, 11: 482-490.

TAN CHENG-YAU; NIK MARIAM NIK SULAIMAN; SOH KHEANG LOH and SIEW-MOI PHANG (2016). Chlorella biomass production in annular photobioreactor using palm oil mill effluent (POME): Effect of hydrodynamics and mass transfer, irradiance, aeration rate and pome concentration. J. Palm Oil Res. Vol. 28(4): 496-509.

TAN SZE PIN; KONG HONG FENG; BASHIR, MOHAMMED, J K; LO PO KIM; HO CHII DONG and NG CHOON AUN (2017). Treatment of palm oil mill effluent using combination system of microbial fuel cell and anaerobic membrane bioreactor. Bioresource Technology, 245: 916-924.

TEE PEI FANG; ABDULLAH, MOHAMMAD OMAR; TAN, IVY A W; AMIN, MOHAMED, A M; NOLASCO-HIPOLITO, CIRILO and BUJANG, KOPLI (2017). Effects of temperature on wastewater treatment in an affordable microbial fuel celladsorption hybrid system. J. Environmental Chemical Engineering, 5(1): 178-188.

TORRES, C I; MARCUS, A K; LEE, $\mathrm{H}$ S; PARAMESWARAN, P; KRAJMALNIK-BROWN, R and RITTMANN, B E (2010). A kinetic perspective on extracellular electron transfer by anode-respiring bacteria. FEMS Microbiology Reviews, 34: 3-17.

XING, J; RAMLI, W; DAUD, W GHASEMI, M; AHMAD, A; ISMAIL, $M$ and BEN, K (2015). Composite membrane containing graphene oxide in sulfonated polyether ether ketone in microbial fuel cell applications. International J. Hydrogen Energy, 40(35): 11604-11614.

ZHANG, X; HE, W; REN, L STAGER, J; EVANS, $\mathrm{P}$ J and LOGAN, B E (2015). COD removal characteristics in air-cathode microbial fuel cells. Bioresource Technology, 176: 23-31. 